\title{
Retraction
}

\section{Retracted: Eigenvalue Comparisons for Second-Order Linear Equations with Boundary Value Conditions on Time Scales}

\author{
Journal of Applied Mathematics \\ Received 1 April 2013; Accepted 1 April 2013 \\ Copyright (C) 2013 Journal of Applied Mathematics. This is an open access article distributed under the Creative Commons \\ Attribution License, which permits unrestricted use, distribution, and reproduction in any medium, provided the original work is \\ properly cited.
}

This article has been retracted as it is found to contain a substantial amount of material from the paper "Eigenvalue comparisons for boundary value problems for second order difference equations," authored by Jun Ji and Bo Yang and it is published in "Journal of Mathematical Analysis and Applications" in 2006 [1].

\section{References}

[1] C. Zhang and S. Sun, "Eigenvalue comparisons for secondorder linear equations with boundary value conditions on time scales," Journal of Applied Mathematics, vol. 2012, Article ID 486230, 10 pages, 2012. 